\title{
Critique \\ Sport mega-events: Can legacies and development be equitable and sustainable?
}

\author{
Jay Coakley \\ University of Colorado, USA \\ Doralice Lange Souza \\ Federal University of Paraná, Brazil
}

\begin{abstract}
Sport mega-events (SMEs) involve struggles to determine the definition of legacy and the outcome priorities that guide legacy planning, funding, and implementation processes. History shows that legacies reflect the interests of capital, and legacy benefits are enjoyed primarily, if not exclusively, by powerful business interests, a few political leaders, and organizations that govern high performance sports. This paper addresses challenges faced by cities and countries that host SMEs, and shows that fair and equitable legacies and developmental outcomes are achieved only when the voices and interests of the general population are taken into account and given priority during the process of planning, funding and implementation. It also explains how full representation in the process of defining and achieving legacies and developmental outcomes may be undermined by populist beliefs about the power of sport.
\end{abstract}

Keywords: sport mega-events, legacy, development, Olympics

Resumo-“Mega-eventos esportivos: Podem desenvolvimento e legado ser equalitários e sustentáveis?" Os mega-eventos esportivos (MEE) envolvem lutas para se determinar a definição de legado e as prioridades que guiam os processos de planejamento, financiamento e processos de implementação de resultados. A história mostra que os legados refletem os interesses do capital, e os benefícios são usufruidos principalmente, se não exclusivamente, por interesses empresariais poderosos, por alguns líderes políticos e por organizações que governam o esporte de alto rendimento. Este artigo aborda os desafios enfrentados pelas cidades e países que hospedam MEE e demonstra que legados justos e equalitários e resultados em termos de desenvolvimento são alcançados somente quando as vozes e os interesses da população em geral são ouvidos e considerados como prioridade durante o processo de planejamento, financiamento e implementação. Ele também demonstra que a representação plena no processo de definição e prossecução de legados e a consecução de resultados em termos de desenvolvimento podem ser prejudicados por crenças populares sobre o poder do esporte.

Palavras-chaves: mega-evento esportivo, legado, desenvolvimento, Jogos Olímpicos

Resumen-“sport mega-eventos: pueden ser legados y el desarrollo equitativo y sostenible?" Los mega-eventos deportivos (DME) implican luchas para determinar la definición del legado y las prioridades que guían los procesos de planificación, financiación financiamiento y ejecución de los resultados. La historia muestra que los legados reflejan los intereses del capital y que los beneficios son disfrutados principalmente, si no exclusivamente por los intereses empresariales poderosos, por algunos líderes políticos y por las organizaciones que dirigen los deportes de alto rendimiento. Este artículo aborda los desafíos que enfrentan las ciudades y los países anfitriones de los DME, y demuestra que legados justos y equitativos y resultados en sentido de desarrollo se logran solamente cuando se considera y se da prioridad a las voces e intereses de la población en general durante el proceso de planificación, financiamiento e implementación. Él también demuestra que la representación plena en el proceso de definición y consecución de los legados y los resultados en sentido de desarrollo pueden ser socavadas por las creencias populares sobre el poder del deporte.

Palabras claves: mega-eventos deportivos, legado, desarrollo, Juegos Olímpicos

\section{Introduction}

Research shows that neither legacies nor positive developmental outcomes occur automatically for the hosts of sport mega-events or SMEs (Alm, 2012; Cagan \& deMause, 1998; Chalip, 2006; Darnell, 2010, 2012; Donnelly,
2008; Flyvbjerg, 2005; Hall, 2006; Horne \& Manzenreiter, 2004, 2006; Maennig \& Richter, 2012; McCartney et al., 2010; Minnaert, 2011; NZTRI, 2007; Solberg \& Preuss, 2006; Spaaij, 2012). Although most research on this topic has focused on host cities and nations in the Northern Hemisphere, the 
research findings have important implications for cities and nations in the Global South where sport mega-events are increasingly seen as vehicles for increasing a host's power and prestige in global relations and achieving developmental goals across social, economic, and political spheres of life (Cornelissen, 2009; Darnell, 2012; Levermore \& Beacom, 2009). This paper addresses the meaning of legacy and development in the context of SMEs and identifies challenges faced by host cities and countries. Our analysis also deals with issues that can be useful within the Brazilian context, as Brazil strives to build legacies for the 2014 FIFA Men's World Cup and the 2016 Olympic and Paralympic Games.

\section{Making sense of legacies and development}

SME legacies generally refer to specific sport-related outcomes for the host city and nation. These include increased sport participation, the establishment of new sport programs, the creation and renovation of sport venues and infrastructure, and the formation of sport-related social capital that revitalizes communities. A broader legacy is the enhanced image of the host city and nation in the eyes of the rest of the world-an image assumed to increase both investment and tourism. In the dominant narratives that accompany SMEs, it is assumed that legacies are inspired and sustained by the event and the performances of athletes.

SME development has most often referred to structural improvements that enhance economic growth and quality of life in the host city and nation, and increase their global and economic power. Structural improvements may also involve new or enhanced communication and transportation systems and needed changes in specific institutional spheres such as education and government.

If legacies and development are to be equitable and sustainable they must be planned, funded, organized, and strategically connected with existing social structures and the everyday lives of local populations. Additionally, unless the processes of planning and implementation are inclusive, particular voices in the host city and nation will be unheard or ignored. Legacies and development are not due to chance, wishful thinking, or beliefs about "the power of sport." They are intentional outcomes grounded in political processes that begin with bid preparation and continue through and following the mega-event.

Of course, there will always be incidental and unplanned outcomes associated with SMEs simply due to their scale and the massive amount of capital dedicated to them. However, the primary beneficiaries of intended legacies and development are those whose voices are represented during bid preparation, initial planning, resource allocation, policy formation, and program implementation. For those who can influence the flow of capital associated with the event, the benefits can be extensive. For socially excluded populations and those who lack power and access to resources, benefits are rare even though they are prominently featured in the promotional narrative used to gain public support for hosting the event.
Achieving legacies that benefit the majority of people in a host city and nation is not likely in connection with SMEs (Chalip, 2006; Darnell, 2012; Hall, 2012; Minnaert, 2011). Recent bids to host these events are driven by the aspirations and actions of well-positioned, powerful people whose definitions of legacy and development are aligned with a neoliberal perspective that reflects their vantage point in local, national, and global power relations. Even when these people are well-intentioned and civic-minded, they do not fully represent the population of a host city or nation, nor are they likely to speak accurately on behalf of those who lack power and resources. However, this dynamic of exclusion is usually obscured by the justification narrative that is created as the bid is planned. This narrative emphasizes that sport has the power to bring benefits to everyone who supports the event and enables the host city and nation to present a good "face" to the rest of the world as the event occurs. This narrative also fosters a sense of self-worth and prideamong citizens. An example of this can be observed in the discourse of the Brazilian former President Luis Inácio Lula da Silva, right after learning that Brazil won the bid to host the Games. He declared, among other things, that Brazil now "conquered international citizenship," "moved from a second-class level to first-class country," and "finally buried its mutt syndrome" ("síndrome de viralata"). That day, thousands of Brazilians went to the streets to celebrate (Coelho, Rangel, \& Mattos, 2009, October 3).

\section{Legacies do not occur automatically}

Research shows that SMEs do not inevitably produce sustainable legacies (Darnell, 2012; Majumdar \& Mehta, 2010; Minnaert, 2011). For example, if a desired legacy is to increase mass sport participation, it will be achieved only if there is a strategy that creates an inclusive planning process through which it is decided (a) where participation will occur, (b) how programs will be funded and implemented, (c) how people will access participation sites, and (d) how participation will be integrated into people's lives - into their family lives, relationships, the rhythm of everyday work and leisure, and into local organizations, schools, and community programs. If the plan does not effectively account for these things, sport participation will neither meet expectations nor be sustainable.

The existence of a sustained sport participation legacy has not been documented in connection with SMEs (Weed, Coren, \& Fiore, 2009). For example, research tracking the sport participation of Australians before, during, and after the 2000 Olympic Games in Sydney indicated that physical activity and sport participation actually declined because Australians spent more time watching televised sports (Australian Sports Commission, 2001; Bauman, Ford, \& Armstrong, 2001). This pattern has been found in other studies, even when athletes from the host nation win more medals than expected (Coalter, 2007; Donnelly et al., 2008; Hughes, 2012; Majumdar \& Mehta, 2010).

This was the case in London, and it disappointed officials 
who promised that the 2012 Games would produce a significant increase in physical activity and sport participation. Even the unanticipated success of British athletes did not bring significant increases in physical activity rates among the general population, nor did it produce improvements in national health and well-being as had been predicted in the bid document. To avoid the embarrassment of failing to create this legacy, members of the organizing committee went back and revised the original bid document to delete their lofty predictions of increased physical activity and sport participation. Correspondingly, the evaluation report submitted following the 2012 Games referred to a variety of polls suggesting that people of all ages had been inspired by the Games although few people had become more active during the five years prior to the Games-despite concerted national efforts to increase participation (Thornton, 2012). Hugh Robertson, the sports minister, explained this by saying that increasing participation is "very difficult" and, if it does increase in the UK, "it is likely to be on a long term, incremental basis" (Conn, 2012, August 14). Changing the narrative in this way was designed to obscure the predictions used to justify massive public expenditures for the games. This was also done in the final reports for Vancouver 2010. After collecting precise data on sport participation and finding no significant changes attributable to the Games, the legacy discussion briefly noted that it was a "very successful Olympic Games that inspired the whole nation and created lasting legacies for local communities" (IOC, 2010). Of course, this conclusion is misleading because it suggests to future bid committees that there was a significant participation legacy when, in fact, none occurred.

Similarly, new sport facilities built for SMEs do not improve community well-being or have lasting meaning for the people of the host city and nation unless there are budgeted resources and existing organizational structures through which effective facility programming can occur. The people for whom new sport programs are intended must be identified in advance and meaningfully included in the planning and implementation process. Additionally, those people must have access to transportation that will take them to and from the facilities, and the programs there must be compatible with their interests and the rhythms of their everyday lives. Without such planning and implementation processes, the facilities will be underutilized or appropriated by people with power and influence and used for their purposes.

Stadium legacy failures are also the norm, and both Beijing and South Africa provide recent examples of Olympic and World cup facilities that sit empty or are underutilized because there were no specific plans to make them part of surrounding communities and the everyday lives of the people who live nearby or have reasonable access to them. Unfortunately, these are not isolated cases (Alm, 2012). The rhetoric used to justify massive expenditures of public money to build new stadiums focuses on how the venues will serve as sites for creating community spirit and lasting positive memories, facilitating processes of renewal, and promoting democracy. However, the reality is that stadiums used for today's SMEs must be designed to meet the requirements of organizers and sponsors rather than the needs of local people or the wishful thinking of event promoters. In the case of the World Cup and Olympic Games, a condition for hosting events is that stadium designs and locations must conform to the mandates of FIFA and the IOC (Cornelissen, 2010; Darnell, 2012). As a result, most stadiums built or renovated for mega-events are designed to serve as barriers, excluding access by local people (Curi, Knijnik, \& Mascarenhas, 2011). This undermines social cohesion and creates resentment among working class people who have no access to the areas created for the events and are restricted from attending future sport events in the venues because ticket prices are increased to pay for construction and operational costs.

Adapting sport venues after the events is difficult, expensive, and seldom practical due to the large debts associated with construction and the costs of staffing and maintaining facilities to meet local needs. A recent survey and analysis of 75 sport venues built to host major events in 20 countries indicated that the "cost of a stadium does not end with its completion" and stadiums will not serve the local population unless there is an explicit and effective plan to do so (Alm, 2012). The result in most cases was a negative sport legacy and increased long term debt for host cities. Additionally, efforts to boost revenues generated by new venues often make them islands of upscale commercial development that are not accessible to local people.

When a desired legacy of an SME is to improve education and physical education, there is a similar record of failure. Improvements occur only when there is an explicit strategy to develop curricula and educational materials well in advance of the event. Additionally, teachers and coaches must be trained to use these materials in real classroom settings, the materials must resonate with the experiences and perspectives of the students who use them, and there must be workable plans to integrate the materials into the regular curricula without disrupting the coverage of required lessons. Converting the good intentions of teachers into sustainable legacies requires at the very least a commitment of resources to the programs combined with structures that support educational improvements and systematic efforts to enable and reward teachers who implement those programs. For example, there was an impressive set of agetargeted educational program designed for primary and secondary schools across the UK in connection with London 2012. The initial acceptance of this program was widespread but using the materials at more than a superficial level was rare because resources were scarce and teachers received no incentives for doing the extra work required to integrate new items into the curriculum ${ }^{1}$.

\footnotetext{
${ }^{1}$ The GetSet program was made available to teachers and then extensively revised after receiving feedback from them. At this point there has not been an evaluation of how the program materials have impacted schools and classrooms, but anecdotal information has largely been positive; see http://getset.co.uk/hom
} 
The legacy most likely to be achieved in connection with SMEs is the creation and growth of high performance sport training programs. Those who manage these programs have strong vested interests in making explicit plans to take advantage of an event and use it to increase funding and other forms of support for their organizations. Administrators, managers and coaches associated with sports in which athletes are expected to do well and win medals are usually the primary beneficiaries in this process, even when their sports are not well suited for mass participation or improving general health and well-being in the host city and nation. Success in a mega-event creates a combination of pride, euphoria, and expectations for the future-a post-event "feel good factor" that officials for elite sport organizations can exploit to increase their public and private funding. People in the general population may never see themselves playing the sports in which elite national athletes have won medals, but they are unlikely to resist new policies and funding priorities that expand and sustain training programs they believe will produce future medals.

London 2012 provides a clear case of how representatives of elite sports exploited the "feel good factor," created when British athletes won more medals than were expected during the Games. Officials for UK Sports, the organization that allocates money from the National Lottery and the government to elite athletes, immediately lobbied to increase its already record breaking budget to prepare elite athletes for Rio 2016. At the same time that they received an $11 \%$ increase in their funding, boosting it to $\$ 560$ million for the four-year cycle leading to Rio 2016, the national government cut funding for schools and sold a number of the playing fields that were or could be used for physical education and after-school sport programs. Also cut was funding to increase general sport participation, thereby undermining the primary legacy of the Games as stated in the original bid.

This shift in priorities also occurred in schools as a large national sponsor provided money to develop and expand competitive inter-school sports involving students with the best sport skills. This funding approach was linked to an overall quest for excellence in UK sports and the goal of winning future medals (Woodhouse, 2010). Providing programs and facilities for the general population was no longer the primary goal even though it had been a highly publicized legacy. In fact, even UK Sport used strict performance-based criteria to allocate their new budget. Because rowing, sailing, equestrianism, and cycling all won medals in 2012, those sports received large funding increases, but table tennis, wrestling, handball, and basketball, which performed poorly in the 2012 Games, had all their funding withdrawn. Paralympic sports, which did very well in 2012 , received a $43 \%$ increase, which boosted their budget to $\$ 113$ million. Sports Minister Hugh Robertson explained this by saying that, "If you give money to sports that won't win a medal, you have to take it away from athletes that will. That's denying athletes in a sport like cycling the chance of winning a gold medal and that's not fair or right" (BBC, 2012, December 23). He never suggested, however, that breaking promises to fund a sport participation legacy was not fair.

A similar shift in priorities occurred in the run up to the 2014 World Cup and Rio 2016. The original focus of the Brazilian Sport Ministry when the Worker's Party won the elections for the president of Brazil was on the democratization of sport through the development of social programs. This agenda, however, became secondary to making sure that Brazil and Rio are ready to host these events (Mascarenhas, 2010). This involved a shift in the entire "organizing principle for the sport and leisure agenda of the country" (Mascarenhas, Athayde, Santos, Mariangela, \& Miranda, in press). An example of this can be observed in the Dossiê de Candidatura (Reis, Souza-Mast, \& Gurgel, 2013) and in the Caderno de Legados (Souza, Almeida, Castro, Bacellar, \& Alves, 2012), both official documents in which the Brazilian government promises a legacy for the country as a result of hosting these SMEs. While these documents contain general promises to promote sport for all and educational sport, the actual planning and budgeting focused almost exclusively on constructing elite sport structures and creating a system of elite sport development so that Brazilian teams and athletes can win medals and the venues in Rio can impress the IOC and spectators from other countries.

Finally, a factor that often interferes with creating sustainable legacies is that SMEs create massive cost overruns and exhaust the spirit and energy of people in host cities and nations (Majumdar \& Mehta, 2010). An example of this occurred in the case of the Rio 2007 Pan American Games. When the bid was presented in 2002 the estimated costs for the event was R \$ 410 million (US \$207 million), but the reported final cost was a reported $\mathrm{R} \$ 3.7$ billion (US \$1.9billion)—an increase of 793\% (Torres, 2009, October 3). The government justified this cost overrun by arguing that there had been changes in the design of stadiums and sport arenas so that they would meet IOC requirements and better position Rio in the bidding to host the Olympic and Paralympic Games in 2016. Despite this massive investment with public money (the cost of preparing for Pan 2007 was higher than the combined expenditures for housing, health and education in the Rio city budget), some of the venues had to be rebuilt or renovated before they could be approved and used to host the Rio 2016 Olympic Games (ESPN, 2009, February 7).

In the wake of the actual events, promises about legacies for the general population are typically suspended or formally revoked because there are no resources to implement and sustain programs. For example, listed expenses for London 2012 were about five times greater than original estimates presented in the bid document. The bid listed expenses ranging from $\$ 2.7$ billion to $\$ 3.4$ ( $£ 1.7$ billion to $£ 2.1$ billion or $\mathrm{R} \$ 5.3$ billion to R $\$ 6.5$ billion) (ARUP, 2002), and a critical evaluation of the bid by a government committee noted that expenses would probably reach $\$ 3.9$ billion ( $£ 2.4$ billion or R\$ 7.5 billion) (House of Commons, 2003). A post-Games report from the organizing committee lists final expenses at 
$\$ 15.03$ billion ( $£ 9.3$ billion or $\mathrm{R} \$ 29$ billion), although it appears that it does not include expenses that were deleted from the official balance sheet for the Games and shifted to various government agencies or listed as general government expenses. Overall, this massive debt, which is typical for host cities and nations, made it difficult to honor the promises made related to legacies benefitting the general population, even though it would be their taxes that would be used to pay off the debt.

\section{The meaning of "development"}

For most of the 20th century, the IOC and other Business International Non-governmental Organizations (BINGOs) have claimed that their events serve the common good by fostering peace and a wide range of positive values. These claims took the form of a sport-for-good narrative which was used by cities and nations as justification for spending public money to host SMEs. But as the cost of hosting SMEs has become excessive, the traditional sport-for-good narrative has been combined with or replaced by a sportfor-development narrative. This is because BINGOs want to show prospective host cities and nations that the public money they plan to spend on an event is an investment that will foster economic development that will offset their costs.

Of course, a version of the sport-for-development narrative had been used during the 19th and 20th centuries to justify hosting World Fairs and Expositions and some large sport events such as the Olympic Games. But it was not until the 1980s that it was explicitly articulated in neoliberal terms so that development was defined as the expansion of private capital and personal consumption. It is under this neoliberal definition of development that governments, corporations, and BINGOs joined together to justify the use of public funds to host sport mega-events by using a clearly articulated sport-for-development narrative in which references to "the public good" are combined with a market driven strategy for national and urban development. In the process, "public good" comes to be measured in terms of attracting capital and wealthy residents who organize their lives around consumption, and quality of life comes to be measured in terms of a consumption index rather than an engaged citizenship index (Whitson \& Horne, 2006).

Although the idea that SMEs can produce development is especially attractive to cities and nations striving for global status and participation, research clearly shows that bidding for and hosting SMEs is not an efficient strategy if the goal is to produce forms of development that directly benefit the general population in sustainable ways (Bolsmann, 2012; Darnell, 2012; deNooij, 2012; deNooij et al., 2011; Hall, 2006, 2012; Hall \& Wilson, 2011; Kay, 2012; Maennig \& Richter, 2012; Majumdar \& Mehta, 2010; Whitson \& Horne, 2006). For example, Manzo's (2012) analysis of the impact of the 2010 World Cup on South Africa led her to conclude the following: ...the underlying outward-oriented development model of sports mega-events is a paradoxical mix of state-led 'big development' and neo-liberal governance - a model that, by its very nature, defers national development while delivering immediate benefits to corporate interests and local political elites. (pp. 182-183)

A similar conclusion was reached by Barnes (2011):

\begin{abstract}
FIFA swirled like a vortex through South Africa, sucking all attention and cash unto itself. This was carefully planned and meticulously enforced...if it didn't make money or noise for FIFA, it wasn't allowed... Meanwhile, South African taxpayers spent billions of dollars on infrastructural improvements and the beautiful new stadiums which are now sitting empty (p. 106).
\end{abstract}

There are at least five specific reasons to be skeptical about broad claims of development attributed to SMEs. First, mainstream social science research on development does not even mention SMEs when identifying factors that produce positive developmental changes in communities and societies. For example, Levermore and Beacom (2009) surveyed texts and journals devoted to development and analyzed 70,000 entries listed in the International Development Abstracts between 1994 and 2009 and found only 12 references to sport, mostly made as afterthoughts. It appears that those who claim that sport produces development often make such sweeping claims about sport's power to solve social and economic problems that experts in the field of development don't take them seriously enough to investigate in their research. They see that the claims are based on faith and wishful thinking rather than established developmental theories or systematic research (Coalter, 2007; Cornelissen, 2009; Levermore \& Beacom, 2009).

Second, SMEs have become incorporated into the entrepreneurial strategies used by influential political and corporate leaders who want to create large scale structural platforms on which they can attract and control new capital flows and sponsor cultural activities that place their cities, nations, and corporations into the global news cycle if not the global economy (Hall, 2006). Such a strategy is used in both hemispheres, but it is increasingly used in Southern Asia, Africa, and Latin America as SMEs are connected with a quest to achieve "global city" status (Sassen, 2000). This was noted by sociologist Simon Darnell in his research on sport and development. He explained that SMEs "in the Global South are increasingly organized, marketed and celebrated as legitimate components of a sustainable and equitable development agenda" even though they are "embedded in a political economy of inequality and underdevelopment" (Darnell, 2012, p. 96). In the process, they enable Northern political and economic interests to be linked with a moral framework that reproduces global inequality and transnational relations of power (Biccum, 2010).

Much like natural disasters, SMEs make it possible for neoliberal interests to reorder social and physical landscapes 
as local government officials seek the expertise and resources to manage the challenges they face. At the same time, powerful corporations and individuals-mostly from the Northern Hemisphere-stand ready to expand their capital markets while they present themselves as progressive global actors coming to the rescue of "underdeveloped" regions of the world. As they intervene, they stress an ideology that promotes personal responsibility, deregulation, privatization, and a free-market ethic that undermines efforts to eliminate systemic inequities, empower previously marginalized populations, and establish security, peace, and social justice for local populations (Coakley, 2011; Cornelissen, 2010; Darnell, 2010).

Third, SMEs such as the Olympics and the men's World Cup are massive undertakings and the time frame for preparation is so compressed that much of the planning process is inevitably shrouded in rushed attempts to complete projects and meet externally imposed deadlines. Additionally, there are no institutionalized mechanisms through which to expect or provide transparency and accountability at any point from the creation of the bid to the final evaluation. This allows powerful actors to take command of many aspects of the larger developmental project and use them for their own interests (Flyvbjerg, 2005).

The top-down planning approach that is widely used when bidding for and hosting SMEs leads many people to conclude that development is a goal most effectively accomplished by established power brokers rather than a process involving political struggles over how the public good will best be achieved (Desai \& Vahed, 2010). As Scarlett Cornelisson (2009) suggests, the discussions that occur when planning these events focus on showcasing a city and nation as "ready for business," rather than assessing the merits of different approaches to development. Consequently, the developmental agenda focuses almost exclusively on creating an infrastructure to expand the flow of capital and attract global elites who will invest in upscale housing and commercial properties. Developmental outcomes such as increased social cohesion, expanded political participation, and new forms of social integration are included in rhetorical support for SMEs, but they are seldom made the focus of specific plans. For example, the Beijing Games clearly accelerated the ongoing process of demolition and reconstruction that reaffirmed the power and resources of the ruling party members.

Fourth, an SME organizing committee consisting primarily of civic leaders and boosters is not an appropriate organization for creating development that maximizes the common good, largely because its members are motivated by images of grandeur, wishful thinking, and personal vested interests. Additionally, these individuals often seek to convert their support of an SME into social and political capital even though their corporations, consulting groups, and construction firms reap financial benefits associated with the events. Documenting these benefits and determining the proportion produced by the public investments dedicated to hosting a sport mega-event is difficult (Gratton et al.,
2006; Preuss, 2004). Accounting details are scattered in many directions due to the participation of multiple public and private agencies, each with its own agenda and budget, and by a storm of emergency allocations, cost overruns, contractor over-charges, bid mistakes, unanticipated expenses, no-bid contracts, gifts, unreported expense accounts, bribes, kickbacks, and other forms of corruptionall of which steer capital flows in the direction of powerful and well positioned actors (Jennings, 1996, 2006, 2011; Jennings \& Sambrook, 2000; Majumdar \& Mehta, 2010)². Under these circumstan-ces, development becomes difficult to identify and measure.

Fifth, BINGOs such as the IOC and FIFA attach rigid conditions to hosting events, and they require that priority be given to their concerns and the concerns of their major sponsors (Darnell, 2012; Lenskyj, 2008). For example, they require new transportation infrastructure to move people to and from venues, and the venues must be built to their specifications, which makes them costly to retrofit so they will meet local needs and preferences after the event is over.

Additionally, any attempt to promote local interests before or during the event is forbidden by the BINGOs that use the event to establish and reaffirm their own brand. In fact, the IOC makes clear in the Olympic Charter that "The Olympic Games are the exclusive property of the IOC which owns all rights and data relating thereto..." (IOC 2011, p. 20). These revenue hungry BINGOs can exploit the sense of urgency associated with development in the Global South by demanding that host cities and nations use a neoliberal approach, regardless of the mode of development that might be best suited for local populations (Maurao, 2010). Priority is given to a market-based model of development rather than one that emphasizes self-determination and sustainability, but this approach is obscured by media-savvy brand managers as they seize opportunities offered by the SME to create media supported narratives that situate BINGOs as progressive global actors (Brennan, 2012, September 14).

In summary, the development that occurs in connection with SMEs is intentional, just as legacies are. The meaning of development is defined by powerful political and economic interests and supported by the BINGOs and their sponsors. The capacity of corporations to use their capital to take advantage of commercial developmental opportunities presented by SMEs has been clearly demonstrated in the past. In general, host cities and nations cannot leverage the event to achieve goals benefitting local populations, because such a strategy will not earn them votes from bid selection committees. As a result, development associated with SMEs favors those positioned to form partnerships with global corporations or to directly access the increased flow of capital that accompanies the events.

\footnotetext{
${ }^{2}$ Identifying those who benefit from capital flows related to SMEs and explaining the strategies they use has been done more by investigative journalists than by academic scholars (see Simson \& Jennings, 1992; Jennings, 1996; Jennings and Sambrook, 2000; and Jennings, 2006).
} 


\section{Using populist beliefs to undermine opponents of sport mega-events}

Opposition to hosting SMEs is increasingly common, but it is usually expressed after the planning framework, legacies, developmental goals, funding priorities, and budgets have been established. As a result it is destined to take the form of protest against decisions already made rather than meaningful participation in the conception of the bid and the integration of the event into the lives of local people.

Creating an opposition movement represents a challenge because the news that a city or nation may host an SME often evokes uncritical support from the general public. Populist beliefs about the essential goodness of sport lead many people to assume that everyone will share benefits of the event. This undermines timely involvement in legacy and development planning and leads people to accept the glowing narrative (and 7-minute video promotion) carefully constructed by professionals hired by the bid committee. When respected leaders from both the public and private sectors provide unqualified support for the overstated and embellished benefits of the event, opposition is defused.

When people believe that sport is essentially pure and good, and that its purity and goodness are transferred to everyone who partakes in it, they see little need to anticipate, plan, program, evaluate, reform, or transform sports for the sake of benefiting the common good. Sport for these people is already as it should be-a source of joy and excitement that transcends work, politics, and the everyday constraints on personal and collective emotional expression. Therefore, there is only a need to dismiss "non-believers" and purge those unwilling to experience the joy and learn the values they believe are inherent in sport and sport participation. This is illustrated in Figure 1.

These unsubstantiated beliefs take the form of deep cultural myths about the power and purity of sports. The myths are so broadly accepted that it is usually personally and politically risky to raise critical questions about sport participation and sport events. This was noted in the following way by management and tourism expert C. Michael Hall, who has studied the economic impact and sustainability of development related to mega-events for over two decades:

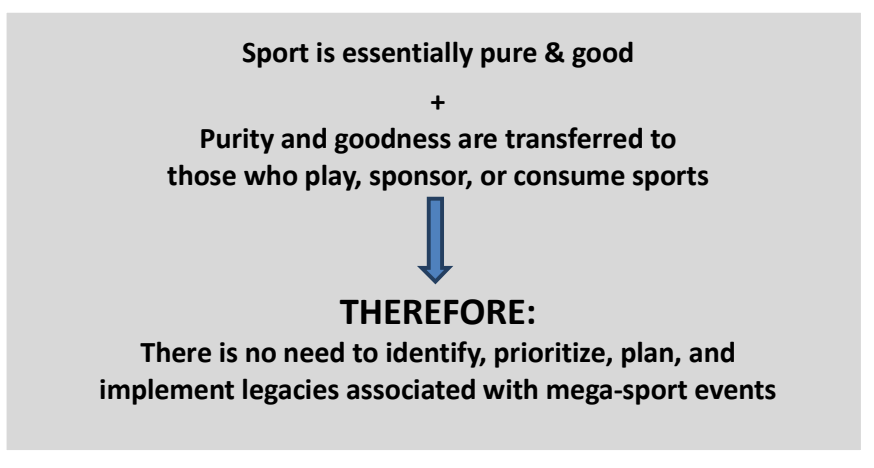

Figure 1. Sport beliefs that undermine the achievement of megaevent legacies.

\begin{abstract}
...to criticize the hosting of mega-events as an economic and social development mechanism is to be doubly damned. For one contends not only with the neoliberal discourse of competition and the relentless pursuit of regeneration but also with the mythologies of the social benefits of sport. Sport is extremely hard to argue against (2006, p. 67).
\end{abstract}

Supporters of SMEs have learned that it is relatively easy to discredit opponents and defuse the impact of critical questions and contradictory facts by quoting respected global leaders who have made unqualified statements about the universal appeal and power of sport as a tool for achieving peace, development, and a wide range of commendable goals. Often cited is a 2004 speech by U.N. Secretary General Kofi Annan who claimed the following:

\begin{abstract}
Sport is a universal language. At its best it can bring people together, no matter what their origin, background, religious beliefs or economic status. And when young people participate in sports or have access to physical education, they can experience real exhilaration even as they learn the ideals of teamwork and tolerance. That is why the United Nations is turning more and more to the world of sport for help in our work for peace and our efforts to achieve the Millennium Development Goals (United Nations, 2004, May 11, p. 1).
\end{abstract}

In one form or another, Annan's statement has been made by a long succession of respected leaders with global or national reputations. Their claims about the power of sports include general statements about social, political, and economic impacts that ignore research and fail to mention the massive public investments and debts that accompany SMEs. But when these statements are cited by bid boosters, most people are less likely to demand answers to critical questions about the specific issues that should be considered before endorsing any sport event that involves the use of public funds and impacts the lives of many people.

In everyday terms, the prospect and process of hosting an SME creates a powerful "emotional community" nurtured by patriots and profiteers alike. Boosters, including those in the media, use a rhetoric that uncritically or strategically (mis)represents it as a working community organized around inclusive participation. This rhetoric is widely accepted because the thought of hosting a major sport event leads local people to feel personally affirmed in a global context. The associated euphoria that comes with the prospect of using sport-a source of one's own joy and excitement-as a platform for presenting one's culture and country to the rest of the world further defuses opposition to the bid and the event. For stakeholders in much of the Southern Hemisphere, it is easy to portray opponents of the event as hopeless cynics, afraid to dream of a brighter future.

\section{Final remarks}

This critical overview of sport mega-events leads to the 
following conclusions:

- Sustainable legacies and developmental outcomes produced by SMEs are intentional, that is, they are defined by particular parties in the initial bid and prioritized through the multifaceted process of planning, funding, implementing, and evaluating all aspects of hosting the event.

- Creating specific legacies and developmental outcomes is a matter of power relations. That is, if particular voices are not represented in the processes of creating the bid, defining and prioritizing legacies and development goals, planning and implementing policies and programs, allocating funds, and evaluating progress toward achieving sustainable legacies and development, they will have no impact in any of these realms.

- SMEs are primarily used by host cities and nations to justify and publicly fund projects that benefit those who are well positioned to access the capital required to complete the projects and stage the event on short notice.

- Business International Non-governmental Organizations (BINGOs) such as the IOC and FIFA have absolute control over the events, and the goals of these BINGOs take priority over the goals of host cities and nations.

- Opposing SME's is difficult because uncritical populist beliefs about sports can be used to undermine oppositional movements and discredit research that contradicts the overstated claims presented in the bid, supported by respected leaders, and repeatedly represented in mainstream media.

At this time there is little chance to do comprehensive critical assessments of SMEs. Even if funding were available, undertaking such a project would be professionally and politically risky because it could only be done over the objections of the IOC, FIFA, and other BINGOs. As previously noted, the IOC owns all rights and data related to the Olympic Games. Although the IOC requires and helps to fund evaluations of each Olympic and Paralympic Games, it retains ownership of the data used in all phases of the evaluation and it has control over the content of each evaluation report.

IOC ownership and control was clearly evident in the evaluation of the 2010 Olympic and Paralympic Games in Vancouver, Canada. The legacy impact study for the 2010 Games was done by a multidisciplinary research team from the University of British Columbia. The team developed a meticulous longitudinal research design to measure 126 sustainable impact indicators in Vancouver and the surrounding region. The research began in 2001 and continued through 2012. This allowed the team to collect data for establishing baseline measures, identifying trends unrelated to the Games, and finally measuring changes attributable to the Games.

Surprisingly, the post-Games report contained only general statements about the impact of the Games, even though the team had data to address 126 potential impacts attributable to the SME. The pre-Games reports had been completed and published with each containing presentations of the impact indicators that were being measured over time. Although rumors hinted that the study found no evidence of any positive impact on any of the 126 indicators, the final evaluation report contained no systematic analysis of those data. Instead, it presented a general overview stating that the Games were well organized and everyone considered them to be a success. The final reports by the IOC Coordination Commission contained no discussion of the 126 indicators but did present many multi-color images and glowing statements about the Games (see IOC, 2010).

At the time of this writing, the full analysis of data for the 126 indicators has not been released, despite repeated requests by the academic community. This is disappointing because this was the most thorough research ever conducted to measure the legacy impact of an SME. However, it also is a stark reminder that the IOC "owns all rights and data" (IOC, 2011, p. 20) related to the Olympic and Paralympic Games and this ownership also gives them direct control over how those data are used and reported. If analyses of those data are not being fully and honestly reported, it is not possible to make informed decisions about the appropriateness of submitting a bid. Therefore, bid decisions are based on unsubstantiated beliefs, wishful thinking, and strategic profiteering rather than reliable evidence about costs and benefits. As long as myths about the power and purity of sport persist, cities and nations will continue to submit bids hoping to share in the benefits believed to come with sport mega-events.

\section{References}

Alm, J. (2012). World Stadium Index: Stadiums built for major sporting events - bright future or future burden? Copenhagen: Play the Game and the Danish Institute for Sports Studies.

ARUP. (2002). London Olympics 2012: Costs and Benefits Summary (Research Report submitted to "the Government, the Mayor of London and the British Olympic Association" by Ove Arup in association with Insignia Richard Ellis, May 21, 2002). Retrieved from http://www.arup.com/_assets/ _download/download368.pdf,

Australian Sports Commission (2001). Impact of hosting the Sydney 2000 Olympic and Paralympic Games on participation and volunteering in sport and physical activity in Australia. Unpublished paper by the Sport Development Unit, Australian Sports Commission, Canberra.

Barnes, T. (2011). Soccer nation/corporation. Journal of Sport and Social Issues 35(1), 101-106.

Bauman, A., Ford, I., \& Armstrong T. (2001). Trends in population levels of reported physical activity in Australia, 1997, 1999 and 2000. Canberra: Australian Sports Commission. Retrieved from www.physical activity.tas.gov.au/trends.pdf.

BBC. (2012, December 23). UK Sport Rio 2016 funding defended by sports minister. BBC.co.uk. Retrieved from http:// www.bbc.co.uk/sport/0/olympics/20830754.

Biccum A. (2010). Global citizenship and the legacy of empire: Marketing development. London: Routledge.

Bolsmann, C. (2012). Representation in the first African World Cup: 'Worldclass', Pan-Africanism, and exclusion. Soccer \& Society 13(2), 156-172.

Brennan, C. ( 2012, September 14). Think Olympics are big now? Just wait. USA Today. Retrived from http://www.usatoday.com/ 
sports/olympics/story/2012/09/14/think-olympics-are-bignow-just-wait/57778012/1.

Cagan, J. \& de Mause, N. (1998). Field of schemes: How the great stadium swindle turns public money into private profit. Monroe, ME: Common Courage Press.

Chalip, L. (2006). Towards social leverage of sport events. Journal of Sport and Tourism 11(2): 109-127.

Coakley, J. (2011). Ideology doesn't just happen: Sports and neoliberalism. Revista da Associación Latinoamericana de Estudios Socioculturales del Deporto, 1(1), 67-84. Retrieved from http://ojs.c3sl.ufpr.br/ojs2/index.php/alesde/issue/archive.

Coalter, F. (2007). A wider social role for sport: Who's keeping the score? London, UK: Routledge.

Coelho, L., Rangel R., Mattos, R. (2009, October 3). Rio 2016: Gente grande. Folha de São Paulo. Retrieved from http:// acervo.folha.com.br/fsp/2009/10/03/604/

Conn, D. (2012, August 14). London 2012 euphoria has died, but will the Olympic legacy live on? The Guardian. Retrieved from http://www.guardian.co.uk/uk/2012/aug/14/london-2012olympic-legacy

Cornelissen, S. (2009). A delicate balance: Major sport events and development. In Roger Levermore \& Beacom, A. (eds.). Sport and International Development (pp. 76-97). New York: Palgrave MacMillan.

Cornelissen, S. (2010). Football's tsars: Proprietorship, corporatism and politics in the 2010 FIFA World Cup. Soccer and Society 11(1-2), 131-143.

Curi, M., Jorge Knijnik, J., \& Mascarenhas, G. (2011). The Pan American Games in Rio de Janeiro 2007: Consequences of a sport mega-event on a BRIC country. International Review for the Sociology of Sport 46(2), 140-156.

Darnell, S. (2010). Power, politics and sport for development and peace: Investigating the utility of sport for international development. Sociology of Sport Journal 27(1), 54-75.

Darnell, S. (2012). Sport for development and peace: A critical sociology. London: Bloomsbury Academic. Retrieved from http://www.bloomsburyacademic.com/view/Sport-forDevelopment-and-Peace/book-ba-9781849665896.xml.

De Nooij, Michiel, Van den Berg, M. \& Koopmans. C. (2011). Bread or games? A social cost-benefit analysis of the World Cup bid of the Netherlands and the winning Russian bid. Journal of Sports Economics. doi: 10.1177/1527002511429825.

Department for Culture, Media and Sport. (2010a). Plans for the Legacy from the 2012 Olympic and Paralympic Games. London: Department for Culture, Media and Sport.

Department for Culture, Media and Sport. (2010b). London 2012: A legacy for disabled people-setting new standards, changing perceptions. London: Office for Disability Issues, HM Government.

Desai, A. \& Vahed,G. (2010). World Cup 2010: Africa's turn or the turn on Africa? Soccer \& Society 11(1-2), 154-167. doi $10.1080 / 14660970903331482$

Donnelly, P., Kidd, B., MacNeill, M., Harvey, J., Houlihan, B., \& Toohey, C. (2008). Opportunity knocks!: Increasing sport participation in Canada as a result of success at the Vancouver Olympics. Centre for Sport Policy Studies Position Paper Series, No. 2. Toronto: Centre for Sport Policy Studies, Faculty of Kinesiology and Physical Education, University of Toronto

Retrieved from http://www.physical.utoronto.ca/ Centre_for_Sport_Policy Studies/Projects_and_Publications/ Position_Papers.aspx.

ESPN. (2009, February 7). Brasil olímpico: Uma candidatura passada a limpo. [Television Program]. Retrieved from https:/ /www.youtube.com/watch?v=8FfCMFoyKII\&playnext=1\&
list=PLD085A5E69E40FE84\&fea ture=results_main.

Flyvbjerg, B. (2005). Design by deception: The politics of megaproject approval. Harvard Design Magazine (SpringSummer), 50-59. Retrieved from http://flyvbjerg.plan.aau.dk/ HARVARDDESIGN63PRINT.pdf.

Gratton, C., Simon S., \& Coleman, R. (2006). The economic impact of major sport events: A review of 10 events in the UK. In J. Horne \& W. Manzenreiter (Eds.), Sports mega-events (pp. 41-58). Oxford: Blackwell.

Hall, C. M. (2006). Urban entrepreneurship, corporate interests and sports mega-events: The thin policies of competitiveness within the hard outcomes of neoliberalism. In John Horne \& Wolfram Manzenreiter (eds.), Sports mega-events: Social scientific analyses of a global phenomenon (pp. 59-70). Oxford: Blackwell.

Hall, C. M. (2012). Sustainable mega-events: Beyond the myth of balanced approaches to mega-event sustainability. Revision of a paper presented at the Global Events Congress IV, Leeds, 14 July, 2010. Retrieved from http://www.academia.edu/822520/ Sustainable_megaevents_beyond_the_myth_of_balanced _approaches_to_mega-event_sustainability.

Hall, C. M. \& Wilson, S. (2011). Neoliberal urban entrepreneurial agendas, Dunedin Stadium and the Rugby World Cup: Or 'If you don't have a stadium, you don't have a future'. In D. Dredge \& J. Jenkins (eds.). Stories of Practice: Tourism Policy and Planning (pp. 133-152). Farnham, UK: Ashgate Publishing.

Horne, J. (2007): The Four 'Knowns' of Sports Mega?Events, Leisure Studies, 26(1), 81-96. doi: 10.1080/02614360 500504628.

Horne, J. \& Manzenreiter, W. (2004). Accounting for mega-events: Forecast and actual impacts of the 2002 Football World Cup Finals on the host countries Japan/Korea. International Review for the Sociology of Sport, 39(2), 187-203. doi: 10.1177/ 1012690204043462

Horne, J. \& Manzenreiter, W. (Eds). (2006). Sports mega-events: Social scientific analyses of a global phenome-non. Oxford: Blackwell.

House of Commons. (2003). A London Olympic bid for 2012: Third Report of Session 2002-03. London: The Stationary Office Limited. Retrieved from http://www.publications. parliament.uk/pa/cm200203/cmselect/cmcumeds/268/268.pdf.

Hughes, K. (2012, August 16). The legacy fallacy: The Olympics doesn't increase sport participation. The Conversation. Retrieved from http://theconversation. edu.au/the-legacyfallacy-the-olympics-doesnt-increase-sport-participation8810.

IOC. (2010). Final report of the IOC Coordination Commission: XXI Olympic Winter Games, Vancouver 2010. Lausanne, Switzerland.

IOC. (2011). Olympic Charter. Lausanne, Switzerland. Retrieved from http://www.olympic.org/Documents/ olympic_charter_en.pdf.

Jennings, A. (1996). The new lords of the rings. London: Pocket Books.

Jennings, A. (2006). Foul! The secret world of FIFA-bribes, vote rigging, and ticket scandals. New York: HarperSport.

Jennings, A. (2011). Investigating corruption in corporate sport: The IOC and FIFA. International Review for the Sociology of Sport 46(4), 387-398.

Jennings, A. \& Sambrook. C. (2000). The great Olympic swindle: When the world wanted its games back. New York, NY: Simon and Shuster.

Jennings, W. (2012). Why costs over-run: Risk, optimism and uncertainty in budgeting for the London 2012 Olympic Games. 
Construction Management and Economics 30(June), 455-462.

Kay, T. (2012). Accounting for legacy: Monitoring and evaluation in sport in development relationships. Sport in Society 15(6), 888-904.

Lenskyj, H. (2008). Olympic industry resistance: Challenging Olympic power and propaganda. Albany, NY: State University of New York Press.

Levermore, R. \& Beacom, A. (2009). Sport and development: Mapping the field. In R. Levermore, R. \& A. Beacom (Eds.), Sport and International Development (pp. 3-25). New York: Palgrave MacMillan.

Majumdar, B. \& Mehta, N. . (2010). Sellotape legacy: Delhi \& the Commonwealth Games. New Delhi: Harper Collins.

Manzo, K. (2012).Visualizing modernity: Development hopes and the 2010 FIFA World Cup. Soccer \& Society 13(2), 173-187.

Mascarenhas, F. (2010). Megaeventos esportivos e Educação Física: alerta de tsunami. Movimento, 18 (1), 39-67. Retrieved from http://seer.ufrgs.br/Movimento/article/view/25260/17340

Mascarenhas, F., Athayde, P. , Santos, M., \& Miranda, N. (in press). O bloco olímpico: estado, organização esportiva e Mercado na configuração da agenda Rio 2016. Revista da Associación Latinoamericana de Estudios Socioculturales del Deporto.

McCartney, G., Thomas, S., Thomson, H., Scott, J., Hamilton, V., Hanlon, P., Morrison, D. S. and Bond, L. (2010). The health and socioeconomic impacts of major multi-sport events: Systematic review (1978-2008). British Medical Journal 340 (7758): 1229.

Minnaert, L. (2011). An Olympic legacy for all? The noninfrastructural outcomes of the Olympic Games for socially excluded groups (Atlanta 1996-Beijing 2008). Tourism Management, doi:10.1016/j.tourman.2011.04.005

Preuss, H. (2004). The economics of staging the Olympics: A comparison of the Games 1972-2008. Cheltenham, Glos.: Edward Elgar.

Reis, A. C., Sousa-Mast, F. R., \& Gurgel, L. A. (2013). Rio 2016 and the sport participation legacies. Leisure Studies. doi: 10.1080/02614367.2012.758304

Sassen, S. (2000). Cities in a World Economy. Thousand Oaks, CA: Sage Publications.

Solberg, H.A. \& Preuss, H. (2006). Major sporting events and long-term tourism impacts. Journal of Sport Management 21(2): 213-234

Souza, D., Almeida, B. S.; Castro, S.E, B.; Bacellar, A., \& Alves, E. (2012, July). Legacies of the Rio 2016 Olympic and Paralympic Games: Promises and Expectations. Paper presented at the World Congress of Sociology of Sport 2012, Glasgow, $\mathrm{UK}$.

Spaaij, R. (2012). Building social and cultural capital among young people in disadvantaged communities: Lessons from a Brazilian sport-based intervention program. Sport, Education and Society 17(1): 77-95.

Torres, S. (2009, October 3). Pan registrou caso de irregularidade e fiscalização frouxa. Folha de São Paulo. Retrieved from http://www1.folha.uol.com.br/fsp/especial/fj0310200922.htm.

Thornton, G. (2012). Meta-Evaluation of the Impacts and Legacy of the London 2012 Olympic Games and Paralympic Games (FINAL REPORT - November 2012; Report 4: Interim Evaluation). Prepared for: Department for Culture, Media and Sport

United Nations. (2004, May 11). Press release SG/SM/9679. Retrieved from http://www.un.org/sport2005/resources/ statements/kofi_annan.pdf
Weed, M., Coren, E., \& Jo Fiore. (2009). A systematic review of the evidence base for developing a physical activity and health legacy from the London 2012 Olympic and Paralympic Games. Canterbury, UK: Centre For Sport, Physical Education \& Activity Research (SPEAR), Canterbury Christ Church University.

Whitson, D., \& Horne, J. (2006). Underestimated costs and overestimated benefits? Comparing the outcomes of sports mega-events in Canada and Japan. In John Horne \& Wolfram Manzenreiter, (Eds), Sports mega-events: Social scientific analyses of a global phenomenon (pp. 73-89). Oxford: Blackwell.

Woodhouse, J. (2010). London Olympics 2012: Sporting legacy. London: Home Affairs Section Briefing for Members of Parliament.

\section{Authors' note}

Jay Coakley is Emeritus Professor of Sociology at the University of Colorado in Colorado Springs, USA . He is currently a visiting fellow in the Department of Sport Development and Management at the University of Chichester in the UK

Doralice Lange Souza is a professor at the the undergraduate and graduate courses in physical education at the Federal University of Paraná

\section{Correspondence}

Jay Coakley

1107 Heatherwood Lane, Fort Collins, CO 80525 USA

E-mail: jcoakley@uccs.edu

Doralice Lange Souza

E-mail: desouzdo@yahoo.com

\section{Acknowledgments}

Grant by Fundação Araucária

Declaration of Conflicting Interests: The authors declared no conflicts of interest exist with respect to the research, authorship, and/or publication of this article.

Manuscript received on February 13, 2013

Manuscript accepted on April 18, 2013 